\title{
MUNICIPAL WEAKNESS AND CRIME: THE CASE OF MICHOACÁN, MEXICO
}

\author{
Jerjes Aguirre Ochoa ${ }^{1}$ \\ Hugo Amador Herrera Torres ${ }^{2}$
}

\begin{abstract}
This article analyzes the existing relationship between legitimacy of local governments and crime in Mexico. The paper discusses the case of Michoacán, Mexico, using correlation analysis. Results establish a link between the lack of legitimacy of local governments and the crime rate. This study supports the view that the structural causes of crime and violence in Mexico are not due to the high demand of drugs in the United States, which has always existed, but to the accumulation of institutional factors which have impeded the Mexican government from enforcing the rule of law. This situation is most clearly manifested at the local level of Mexican government.
\end{abstract}

Key Words: Organized crime, Michoacán, Drug war, legitimacy.

\section{INTRODUCTION}

The magnitude of criminal violence in Mexico has increased in recent years. During the period 2006 to 2012, or the six years that last a presidential term in office, more than 60,000 deaths have been recorded. This high number of deaths can only be compared with the deaths in the twentieth century during the Mexican Civil War of 1917. This data and the grave consequences of the so-called War against Drugs initiated by President Calderon in 2006 reflect the seriousness of violence in Mexico.

The approach taken by the Mexican government to attack the problem of drug trafficking has focused on the use of military troops and police forces. This strategy has consisted of direct confrontations with the drug cartels, seeking arrest of major cartel leaders. The arrest and death of criminal bosses broke the existing power balances created among the criminal groups and generated bloody battles for the control of the cartels and the operation of the markets left open by leaderless groups. With this tactic, Mexico and the United States have done little to understand and resolve the root causes of violence in Mexico.

Changes in the drug routes and the sale of high-powered arms in the United States acted as violence catalysts in a situation of deep institutional weaknesses in Mexico. The Mexican government is incapable to

\footnotetext{
${ }^{1}$ Researcher at the State University of Michoacán de San Nicolas de Hidalgo, México, since 2003. Member of the National System of Researchers of Mexico and Michoacán Academy of Sciences. E-mail: jerjes_99@yahoo.com

${ }^{2}$ Hugo Amador Herrera Torres. Biografia: Young researcher at the State University of Michoacán de San Nicolas de Hidalgo, México, since 2013. Member of the National System of Researchers of Mexico and Michoacán Academy of Sciences. E-mail: jerjes_99@yahoo.com
} 
enforce law thus creating vacuums of power and institutional gaps, which have been filled by criminal groups (Aguilar, 2015).

The structural causes of crime and violence in Mexico are not due to the high demand for drugs of the United States, which has always existed, but most likely is due to a host of institutional factors. Mexican government in its three levels, federal, state, and municipal, has been unable to stem the tide of violence unleashed by the presence of organized criminals. The wave of violence that exists in Mexico does not exist in the United States, although it serves as the principal world drug market. In fact, the violent behavior in the drug distribution chain appears to be on the decline in the United States. Other illicit world markets follow a similar decline in violence. The Japanese Yakusa that controls diverse illicit markets in Japan does not tend to act with the violence and brutality that use Mexican criminal groups. One important reason for this is the deep institutional weakness that impedes the Mexican State for establishing a minimum limit in the violence deployed by organized crime criminals.

The explanation for the weakness of the Mexican government and its relation with violence deserves further analysis. A starting point could be the study of government levels. This paper focuses on local governments. It is assumed that deep institutional weaknesses at the municipal, or local, level explain in great part why so much violence has taken place recently (Aguirre, 2013). Ever since the beginning of the Drug War in Mexico in 2007, organized crime has assassinated 82 mayors, 64 municipal officials, 13 candidates, 39 political leaders, and various local political leaders (Trejo and Ley, 2014). Being the level of government closest to its citizens, it was hoped that local authorities would take the first step to stop criminal activity. However, according to the Mexican federal government, around 75\% of the 2,457 municipal governments in Mexico have been violated or infiltrated by organized crime. Approximately 1854 local governments have few tools against the penetration of the cartels. The infiltration of criminal groups in local governments affects the economic, social, cultural and political activity of the municipality.

By constitutional mandate, local governments have as their mission to assure, maintain and restore law and order, besides protecting the interests of the community, preventing the occurrence of misdemeanors and crimes. As the governmental organ closest to the populace, municipal governments have the obligation to be the first instances against crime. Nevertheless, just the opposite has occurred; criminal groups have converted these local governing bodies into the first steps of governmental penetration and cooptation. The majority of criminal groups have obtained control of local governments through direct threats to the mayors themselves or through more subtle means, such as financing of electoral campaigns, obtaining and coopting the leaderships of political parties and by participating actively in local power elites. 
This paper discusses the weakness of the municipal governments as a substantive factor to explain the wave of crime and violence in Mexico. Local governments are the weakest link in the chain of the Mexican government. Despite this well-known fact, little or no scientific investigation has taken place to study the degree or scope of weakness existent at the local level of government and its paper in a structural explanation of violence in Mexico. The magnitude of the weaknesses in the municipal governmental structure becomes evident upon analysis of the number of cases in which local authorities have been involved, directly or indirectly, with criminal groups. The best example occurred with the death of 43 students in the municipality of Iguala, Guerrero, Mexico. This case exposed the existence of a chain of criminal complicity between criminal groups dedicated to heroin trafficking and municipal authorities.

In this context, the analysis of the state of Michoacán was undertaken through dominant approach analysis (qualitative over quantitative) to determine the relationship between municipal weakness and crime. The investigation hypothesis is that the weaker municipal governments are those that present a great level of violence generated by the presence of disputes among groups of organized crime. This is explained by the lack of legitimacy and authority that are filled by organized crime groups. This is expressed in local police forces, that depending directly of the Presidentes Municipales (majors) that represent an illegitimate local government with no resources, equipment and acceptance among the citizenry to be able to do their jobs properly and accomplish the rule of law.

\section{MUNICIPALITIES IN MEXICO AND MICHOACÁN}

Michoacan is located in the western part of Mexico and lies within the Balsas and Lerma Rivers, Chapala Lake and the Pacific Ocean. The state forms part of the Neo-Volcanic Axis and the southern part of the Sierra Madres Mountain Range. The land area is 59,928 square kilometers, representing 3\% of the country. The population is around 3,985,667 inhabitants. The state has a similar geography to Columbia, which facilitates the production of drugs such as marijuana and more recently synthetic drugs. Michoacán is found almost at the geographical center of Mexico and has quick access to the two main cities of Mexico, Mexico City and Guadalajara; and has an industrial port city, Lazaro Cardenas.

According to the United Nations Development Programme (UNDP, 2007), Michoacán has a human development index factor (IDN) similar to Paraguay, San Vicente and the Grenadines. According to the same source, regional inequality exists. The state capital, Morelia, and its surrounding areas have the highest quality of life index and the southern regions of the state, isolated by mountain ranges, have the lowest. The state population is primarily employed in services, which represents $37 \%$ of the population. Michoacán has 113 municipalities (Municipios). 
Municipality is a term that describes the administrative entity or township that governs a locality or a group of localities within a determined region. Municipal areas are territorial divisions of a state (a federal entity) with neighborly relations governed by a city council consisting of a mayor, a trustee and aldermen. Its political equivalent might be the political system of a town or a city in the British political system. A municipality in Mexico is a level of government that has been subjected to a long political discussion. Its validity as an effective, useful, and representative government for its citizens can be likened to the political controversies that sprung up between federalists and centralists from the nineteenth century that provoked among other actions, the excision of the states of California and Texas from Mexico in 1847.

There have been few structural changes over the years that have helped municipal authorities to convert this level of government into clear and effective government. Mexican constitutional reforms at the beginning of the 1980's and at the end of the 1990's boosted municipal autonomy as a democratic standard; but little was discussed or changed about the specific channels through which local governments could achieve an effective government for the people. Accountability is only slightly enforced (Cejudo, 2009). Local governments themselves do not have financial autonomy and depend almost completely upon the budget that the federal and state governments grant them. Therefore, they lack resources to achieve a fully effectual plan for the provision of resources for their citizens; they are ineffective and unrepresentative of their communities. Public services, likewise are limited.

One of the main political discussions in Mexico has been the need for greater autonomy for local governments seeking to achieve greater benefits for their respective communities. This desire for greater autonomy has been constant in Mexican society, which seeks greater civil participation and action to improve living standards. Nowadays, local governments in Mexico are the protagonists in their own struggle for strengthening governmental capacity. Serious controversies are currently taking place among municipal, state and federal governments over the management of public resources, the carrying out of public works, tax capacity, and particularly the topic of public safety.

At the heart of local problems is the lack of mechanisms preventing evaluation of the performance of local governments and the reelection of popular representatives. Mayors cannot be reelected in Mexico. Their terms are limited to a space of three years. Mexico constitutes the only country in Latin America in which the citizens do not have the opportunity of evaluating their government representatives at the voting urns.

During the period of three years, the local governments usually end up learning the strategies about their governmental responsibilities in a steep learning curve at the beginning. It is not until the second or third year of government that they actually start governing without learning the ropes. Without mechanisms in place that 
permit the citizens to approve by reelection or punish by electing other officials, there are not many incentives for elected officials to do a good job that would guarantee continuing in their offices for another three year period.

The original Mexican Constitution of 1917 contemplated reelection. However, in 1933 a reform prohibited the reelection of all publically elected offices. The effect of this measure was to centralize power in a hegemonic political party and to deposit all the political control of mayors and legislatures in the Presidency of Mexico. For more than 60 years, this reform permitted the consolidation of presidential control over the political life at a national level, converting Mexico into a perfect dictatorship. Municipal mayors could not establish longterm projects in the absence of reelection; professionalization of public service officers cannot not take place; and in many cases, the mayors dedicate their maximum effort toward increasing their personal wealth during the three years that they remain in office.

The lack of professionalism in the staff of local government has generated ineffective police protection. Each municipality in Mexico has its own police force. However, most municipal governments do not have a clear policing model, which added to political tradition that has not made public safety a priority, has an end result in local police forces that are fragile, ineffective and vulnerable to the influence of organized criminal groups. Police academies do not exist, and there is no formalized selection of police recruits. Needless to say, formal police career training at the local level does not exist either. Municipal police jobs are awarded to any local person with middle school studies. Many times these jobs are assigned to individuals as payment for electoral favors.

Given the scarcity of employment options, the guaranteed income of a municipal police officer offers a viable work option for three years, the duration of a local administration. Thus, the job of municipal police officer is equivalent to temporary employment with the right to carry a gun to monitor and protect the community. It is no wonder why the local police forces are ineffective and corrupt, and why their ineffectiveness and corruption contribute to the perception of illegitimacy in local governments. The arrival of a new mayor and town council every three years also means the entry of new police officers join the force, repeating the cycle of inadequacy instead of following a professional training and selection process. In this manner, local governments fail to provide one of their main obligations: public safety.

On the other hand, a link exists between the levels of legitimacy and the societal support to formal judicial process (Tyler and Fagan, 2008). Mexican people do not trust in local orders and rules. In order to effectively reduce the crime rate and create safe communities, the local police force must be able to count on the cooperation of community residents. According to public opinion, this cooperation potentially involves abiding by the law and working with police forces to combat crime. In the case of Michoacán, Mexico, this cooperation is nonexistent, due to the low recognition of the legitimacy of local government and their own local police force. Municipal police is perceived as corrupt and representative of an illegitimate and corrupt government. 
One of the origins of the defeat of the Knights Templar in Michoacán, main cartel in Michoacán, in 2014 was precisely the cooperation that the community provided to the Mexican federal police. Without the logistical support of the communities, the dismemberment of the Knights Templar would not have been possible.

In the absence of mechanisms to evaluate governing officials; with a dependency on centralized government; and without sufficient financial resources at the municipal level, municipal governments have converted into mere administrators of a central power. Local legislators play an even worse part as representatives of their political parties instead of the local citizens that they represent. Legislators in Mexico cannot be reelected beyond their three-year period of elected office. The legislative decisions depend on the decisions of incumbent elites of the political parties that have been elected. Local districts usually only see their legislators during the electoral campaigns. After being elected, they have no incentive to hear the opinions of their constituents.

The lack of constitutional checks and balances has generated inefficient and corrupt government structures. As a result, informal agreements dictate the rules of coexistence. According to Morris (2011), Mexico has established a system of informal institutions based on friendship, loyalty, family, and economical relationships that have little to do with the written law.

The existence of informal and illegal relationships in local governments provoked the relatively easy inclusion of drug traffickers and other criminal groups in the public electoral theater. With the demands of the drug market in the United States, criminal groups began to weave relationships based on bribes and threats to local police and officials. The undermining of institutional legitimacy has reinforced the presence of regulatory codes of conduct and informal rules in the places where these groups operate.

With the democratic opening that led to a higher electoral competition, candidates for municipios have had to spend great quantities of money on political campaigns. These resources are much greater that the official spending limits imposed by the electoral authorities. A mayoral campaign constitutes a high-risk gamble to those who seek to be elected to public office, and the winning candidate can only hope to recover the investment made during the campaign while he is in office (Ugalde, 2013). According to the former CEO of the electoral commission in Mexico:

The electoral democracy in Mexico has become more expensive in recent years, both in its budgetary aspect to illegal and unregistered financing. Although the electoral reform of 2007 reduced public financing for electoral campaigns, in reality, campaign costs have spiraled and with it, so have the flow of private and illegal resources. The more expensive electoral campaigns have a corrupting effect on government functioning and the democratic system as a whole.

This fact constitutes a political perversion; elected mayors have to rob the little money that they receive from the federal government to offset their campaign expenses. Given the impossibility of being punished by 
citizens without reelection, the mayors tend to be remembered by the citizens as part of a carnival of corruption. The degree of legitimacy of mayors in municipalities is very low.

Most of the municipalities in Mexico share the situation described above. The presence of drug traffickers in the municipal governments of Michoacan was a catalyzing element in the accumulation of democratic contradictions described in this section. Municipalities in the state of Aguascalientes did not experience the same crisis as Michoacán due to the inexistence of criminal groups. The failure of Mexican democracy can be condensed in the image of a mayor in Michoacán asking mercy to drug lords.

\section{LITERATURE REVIEW}

Most of the references on fragile states have a national character. For fragile states we understand those countries where national and local authorities are unable to deliver essential public goods or where their right to do so is challenged by illegal rivals to their authority. There are not many terms that refer explicitly to the specific level of fragile municipal governments. However, it is of particular importance in the case of Mexico, where in recent years, great debate has been given to the degree of authority and autonomy that the municipal governments should have.

Anten (2012) sustained that "despite the ongoing debate on whether the label 'fragility', is a valid, appropriate, and fitting description of these states; the concept of a group of poor countries, where power and authority structures cannot provide their citizens with basic public services and goods provides a resounding description." For Anten, there are two components of fragility: capacity and legitimacy. Capacity refers to the ability of the state to provide public goods, services and rights to its population; while legitimacy denotes the ability to recognize, accept, and affirm the authority of the state throughout its territory. When a state lacks these, it is said to be fragile.

For the OCDE, fragile states are described as those that have "little ability to perform basic functions of governing a population and its territory and cannot develop a mutual construction that reinforces and strengthens relationships with society" (OCDE, 2011).

While these definitions have been used in reference to national states, certain elements can be used in the analysis of local governments. This paper talks about fragile or failed municipalities. Municipalities in Michoacán do not provide basic public goods and services to its citizens. The state of Michoacán contains various municipal governments that can be called fragile. Structurally, municipalities lack the resources and administrative capacity to meet the needs of its citizens. This generates illegitimate governments that fail to comply with the law, thus creating a vicious circle from which they cannot escape. 
Other of the main components of stability and order that a governing state can offer is legitimacy. Citizens who perceive the governing body as legitimate are likely to consider their institutions as valid sources of social control. Legitimacy plays an important role in any criminal offensive because it constitutes a link between power and the people. Legitimacy has the potential to be an important social mechanism connecting the actions of the state to the penal conduct of individual behavior. Lack of legitimacy could lead citizens to reject the monopoly of physical force and remove the social commitment with these same institutions, breaking social control (Nivette, 2014). In Michoacán, many citizens distrust their mayors and its municipal police, and do not turn to them to report criminal situations. The population believes that in any police offensive, that their municipal forces would be doomed to failure.

Legitimacy is closely linked to rule of law. The concept of legitimacy is derived from the belief that citizens have on the regulatory adaptions of government structures, staff and processes (Tyler, 2006). When the members of a community believe the government is legitimate, they are more likely to submit to authority and laws. Legitimacy denotes the popular acceptance of the right government officials to govern. Legitimacy implies popular acquiescence to the authority of government.

According to Levi (2006), legitimacy can be divided into two characteristics: 1) representative and accountable to the people they are meant to serve, and 2) effective and capable of protecting the population from violence, ensuring the security of their property rights, and administration and provision of other public goods that the population needs and wants. The local governments in Michoacán do not meet these conditions.

Michoacán and its municipalities have lived under the influence of criminal groups since the 1970's, since the beginning of marijuana cultivation in the state. However, it was not until the twenty-first century with the rise of drug trafficking in Mexico that the state was inserted into drug trafficking rings. Local municipal governments found themselves trapped and made into the prey of organized criminal groups. With this, an unstoppable wave of violence began.

During the elections for mayors, legislators and governor in 2011, the Ministry of the Interior and the Michoacán state government revealed that state elections were marred by threats against candidates in 18 of the 113 municipalities of the state. During the same election, four candidates sought protection from the State Attorney's Office (El Universal, 2011). At the same time, the mayor of La Piedad, one of the four major cities of the state, was killed 11 days before the elections.

Traditionally, organized criminal groups in Michoacán showed little interest in political activity; however, in 2011, they showed greater interest in aligning themselves with local political elites. This explains how local political participation permitted them to control the local police forces, thereby facilitating the movement of drugs, 
the installation of laboratories, or merely to perform openly and without fear the functions of mediation and extortion among particular citizens and groups.

The lack of legitimacy and the vacuum of authority in local governments validated the extortion and other crimes related to rent extraction to population. Criminal groups offered protection to the community against common crimes, thus taking over the functions of local police. An important part of the success of organized crime in Michoacán was this same offer to society to effectively protect communities against common crime and other criminal gangs. At first, local society accepted these agreements; but afterwards, they realized that they had made a pact with the devil when their quotas for protection began to rise. According to Herrera (2011), the municipalities of Michoacán have a low level of legitimacy when evaluating the services provided to citizens. A report from the Government Audit Office mentioned 6,108 diverse observations from 103 municipalities. Specific municipal governments, like Susupuato, with high poverty and crime levels, had around 250 observations alone, although its budget is 3 million dollars. Considering that the total state budget is around three thousand million, and the state government received 500 observations, one can visualize the extent of the financial irregularities that exist in local governments. Add these irregularities to poor quality of service and the result generates lack of authority for municipal governments.

Another factor that creates these situations is geographical isolation. During many years, municipalities in the interior of the state, especially from the area denominated Tierra Caliente, suffered from underdevelopment due to geographic isolation. It is no mere coincidence that these isolated areas are precisely where criminal groups' presence is more marked.

In the absence of local authority, organized crime groups have engaged in activities that should be performed by local institutions of law and order. Such groups have participated in a wide range of activities, such as collecting rights for market space and small businesses, charging payment for permissions for parties, supporting private debt collection among citizens, controlling small drug dealers, selling protection to local citizens against other criminal groups, as well as providing support to groups in political and economic conflict among groups of the same or neighboring communities and regulating crops and the agricultural prices.

\section{METHODOLOGY AND RESULTS}

This study used a mixed methodology combining depth interviews with statistical correlation analysis. For statistical analysis, researchers observed municipal weakness through legitimacy, composed of two main variables, which according to Tyler (2006) are representativeness and governmental effectiveness. As a proxy indicator of representativeness, the vote percentages obtained in the 2012-2015 mayoral elections in relation to 
the total municipal voter register (the independent variable) were analyzed. The premise was that the higher amount of votes equated a higher level of legitimacy.

The second independent variable, which is related to efficacy, was calculated from the Basic Municipal Performance Index, of Flamand, Martinez and Hernandez (2007). This index includes normalized indicators related with infant mortality, the percentage of the population that has completed primary education, gross value added per capita census, employment level, tax levels, social participation, types of housing and running water availability. The number of crimes reported by the statistical office of Mexico was used for the dependent variable. The indicators that make up the dependent and independent variables were obtained for the 113 municipalities in the state. All variables were analyzed with simple correlation analysis.

In the qualitative part of the study, 100 depth interviews were realized using snowball technique. These interviews were recorded and transcribed by a typist and analyzed using the Atlas Statistical Package. The interviews lasted 90 minutes.

The results obtained from statistical analysis showed a low level of correlation between legitimacy and crime when considering the municipalities of the state as a whole. However, the correlation between variables increased as the study focused on regions. In the municipalities of Tierra Caliente, Infiernillo and Sierra Costa (ridden by the presence of organized crime) legitimacy was low, the performance of local government was low and the number of criminal activity was high. The correlation between these variables increased even more when statistics were run on only those municipalities classified as sources of crime. In regions of the state with lower levels of violence, a lower level of correlation was observed. For example, in the area of the state capital, Morelia, which has a lower level of violence, the correlation between crime and legitimacy was relatively low. This strengthens the prospect of a positive relationship between crime and legitimacy.

In the quantitative analysis, the variable of legitimacy remained low in most municipalities in Michoacán. Important to note is that in municipalities with higher levels of crime, such as Apatzingan and Nueva Italia, respondents stated emphatically that there is little trust in local government and openly pointed out that municipal authorities dedicate their time robbing the people and have always been in collusion with criminal groups. Both in municipalities with high and low levels of violence, interviewees demonstrated a tacit acceptance of bad government and tolerance toward corruption as a normal form of coexistence between the rulers and the ruled.

These results made sense when explaining the relative approval that criminal groups had in many regions in Michoacán, particularly in those municipalities with greater levels of violence. The legitimate authority that should have been exercised at the municipal level was replaced by an authority that was based on the violence that criminal groups employ. It is no coincidence that the beginning of the end for organized criminal groups on a large 
scale in Mexico came at the exact time of the organization of society in self-defense groups formed against criminals.

\section{CONCLUSIONS}

Violence in Mexico during the first years of the twenty-first century should be seen as a civil war that erupted as a consequence of profound economic, political and social contradictions dating in many cases from the formation of the Mexican nation in the late nineteenth century. The demand for drugs in the United Sates should be viewed as a catalyst for a situation of deep institutional crisis in Mexico.

However, there exist few voices and little academic reflection on the need to make structural changes in the Mexican political system. It is necessary to place emphasis on building greater institutional legitimacy. Democratic transformations are indispensable. Law and order should have sufficient force in government to provide strength at all three levels of government to ensure its compliance.

The strategy followed by the Mexican government in its fight against organized crime has lacked a main identification of the central problem: institutional perspective. This problem becomes more acute in local government. This level of government has been abandoned in the actions that the Mexican State has followed. There is no resources nor mechanisms, to evaluate the work of mayors and councils. Municipalities are easy prey for criminals who tend to fill gaps in authority. Assuming that state governments also have serious problems of legitimacy stemming from institutional weakness, one reaches a fuller explanation of the emergence of violence.

This situation is not unique to Mexico, but has also been experienced in Columbia. According to Ojuela, (2000), the weakness of the Columbian state and its absence of authority in much of its territory has been an incentive for the expansion and consolidation of drug trafficking cartels. The criminal groups challenge the social order and through corruption and violence, seek to insert themselves in the political arena. Like Mexico, Columbia has experienced a stage of political transition that has generated conditions of institutional weakness of state and local governments.

Building higher levels of legitimacy is a long process that goes along with making changes in the Mexican political system, educating the population, and raising income levels. Underlying the process is the political discussion about the convenience of granting greater or lesser autonomy to local governments.

However, there are positive signs. At the end of 2014, for the first time in 80 years, a political reform was approved in Mexico that permits reelection of federal legislators, regional legislators, and mayors, to start in 2018. The possibility of reelection of mayors opens the door to a closer scrutiny of society that may be beneficial to help improve the legitimacy of mayors and help them to become guarantors of the interests of the citizens they represent. 
It should also be noted that most of the municipal police in Michoacán have been replace by police officers from the capital city who in what the state government calls a unified command. Municipal governments no longer have control over the local police. For the medium term, this substitution might pave the way for many changes planted in this paper. The centralization of police control by the state authorities can help to reduce the interference of local criminal groups with police groups.

Nevertheless, the reform of 2014 does not definitely resolve the problems of institutional weakness. Reelection is bound to the reform of 2015 that can only be made with the political parties that have been elected to municipal governments. This takes away some of the autonomy of the citizens. These reforms do not attack the fundamental problem of the local governments' lack of financial resources. Even worse, these reforms have not obeyed the consensus among Mexican elites to strengthen institutions as a way to attack the root of the problem of homeland security.

The rapid recovery of the drug cartels after the arrest or death of their leaders, shows the need to tackle the institutional causes of crime in Mexico. The level of government we should start the municipalities. This is the only way to control the negative externalities of drug trafficking, a phenomenon that Mexico and the United States will have to live and cope in the coming years. It is clear that the strengthening of institutions is the only effective way to attack the problem of violence caused by illicit markets.

\section{REFERENCES}

AGUILAR CAMÍN, Héctor. 2015 La captura criminal del estado Nexos, January 2015, México.

AGUIRRE, Jerjes; Herrera, Hugo. 2003, Institutional Weakness and Organized Crime in Mexico: the Case of Michoacán. Trends in Organized Crime - 16:2, 221-238.

ANTEN, L., I. Briscoe and M. Mezerra. 2012 The Political Economy of State-Building in Situations of Fragility and Conflict: From Analysis to Strategy. Conflict Research Unit, Netherlands Institute of International Relations 'Clingendael'.

CEJUDO, Guillermo y Alejandra Ríos. 2009 La rendición de cuentas del gobierno municipal en México. Documentos de trabajo México: CIDE. 224

FLAMAND, Laura, Sárah Martínez y Alberto Hernández 2007. Metodología de cálculo. Índice de desarrollo municipal básico. Tijuana: Colegio de la Frontera Norte.

HERRERA, Hugo. 2011, Evaluación del desempeño municipal. Propuesta metodológica para los municipios semi-urbanos del Estado de Michoacán. México: INAP, A.C.

LEVI, M. 2006. Why we need a new theory of government. Perspectives on Politics, 4, 5-19. 
MORRIS, Stephen D. 2011 Mexico's Political Culture, the Unrule of Law, and Corruption as a Form of Resistance. Mexican Law Review, 3(2): 327-342.

NIVETTE, Amy E. 2014. Legitimacy and Crime: Theorizing the Role of the State in Cross-National Criminological Theory. Theoretical Criminology, 18(1): 93-111.

JAVIER, Orjuela Escobar Luis. 2000, La debilidad del estado colombiano en tiempos del neoliberalismo y el conflicto armado. Revista Colombia Internacional, Mayo - Diciembre de 2000, pag 103 - 116.

TYLER, Tom R. and FAGAN, Jeffrey. 2008. Legitimacy And Cooperation: Why Do People Help the Police Fight Crime in Their Communities?. Ohio State Journal of Criminal Law 231-275.

GUILLERMO, Trejo y SANDRA, Ley 2014. Municipios y crimen organizado en México, La experiencia de la guerra contra el narcotráfico muestra que el apoyo federal fluye a partir de criterios partidistas. Periódico El País, 20 de febrero de 2015, http://internacional.elpais.com/internacional/2015/02/20/actualidad/1424404906_886826.html

TYLER, T. R. 2006, Psychological perspectives on legitimacy and legitimation. Annual Review of Psychology, 57, $375-400$

UGALDE CARLOS, 2013 , En las urnas: Más dinero, más corrupción, Revista Nexos, Agosto 2013.

Trabalho enviado em 17 de abril de 2015.

Aceito em 25 de maio de 2015. 